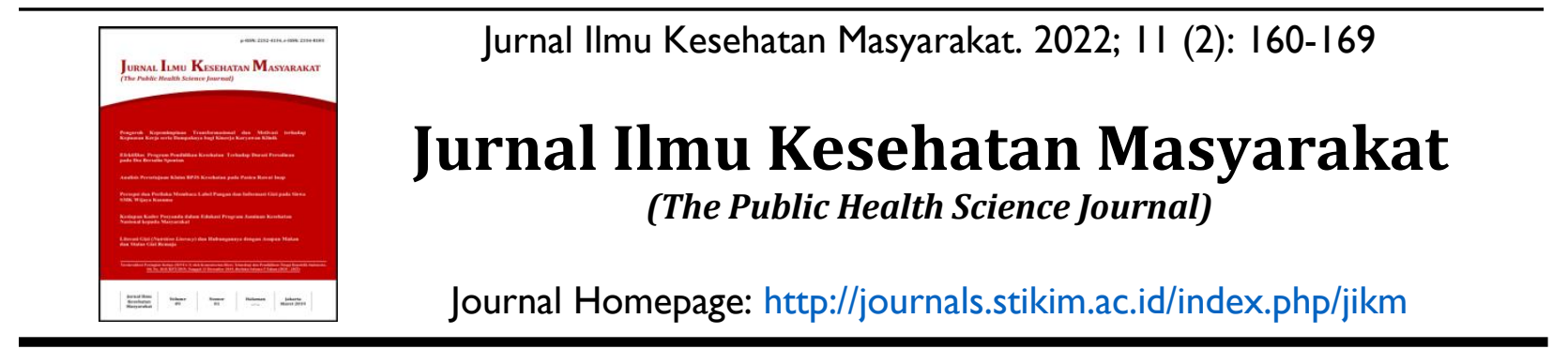

\title{
Beban Kerja, Dukungan Rekan Kerja, Lingkungan Kerja dan Iklim Kerja terhadap Tingkat Stres Kerja Perawat
}

\author{
Anna Riana ${ }^{1}, \mathrm{Nina}^{2}$, Rindu ${ }^{3}$ \\ ${ }^{1-3}$ Program Studi Magister Kesehatan Masyarakat, Departemen Kesehatan Masyarakat \\ Universitas Indonesia Maju
}

\begin{abstract}
Abstrak
Stres kerja dapat mengakibatkan karyawan merasa tertekan dalam menghadapi pekerjaan dan bisa menurunkan kinerja. Tujuan penelitian ini untuk mengetahui pengaruh langsung dan tidak langsung serta besaran pengaruh beban kerja, dukungan rekan kerja, lingkungan kerja dan ikllim kerja terhadap tingkat stress perawat puskesmas dalam penanganan COVID-19. Jenis penelitian kuantitatif, desain penelitian menggunakan pendekatan cross sectional dengan Struktural Equation Modelling. Populasi dalam penelitian ini adalah seluruh perawat di 44 puskesmas wilayah Kabupaten Tangerang dengan jumlah perawat sebanyak 290 orang. Sampel dipilih secara purposive sampling dengan jumlah 82 responden. Pengumpulan data menggunakan kuesioner. Stres kerja dipengaruhi oleh beban kerja sebesar $18,07 \%$, dukungan rekan kerja sebesar 17,59\%, iklim kerja sebesar 19,70\% dan lingkungan kerja sebesar 25,64\%. Model mampu menjelaskan variabilitas data sebesar $99,74 \%$, sedangkan $0,26 \%$ dijelaskan oleh variabel lain yang tidak dikaji dalam penelitian ini. Diharapkan perawat untuk menciptakan lingkungan kerja yang kondusif seperti menjaga hubungan yang baik dengan sesama rekan perawat, saling mendukung dalam pencapaian prestasi kerja serekan sejawatnya dan menjaga fasilitas yang diberikan oleh puskesmas untuk menunjang kerja perawat.
\end{abstract}

Kata Kunci: Beban Kerja, iklim, lingkungan, rekan kerja, stres.

\begin{abstract}
Job stress can cause employees to feel pressured in the face of work and can reduce performance. The purpose of this study was to determine the direct and indirect effects and the magnitude of the influence of workload, support from coworkers, work environment and work climate on the stress level of puskesmas nurses in handling COVID-19. This type of research is quantitative, the research design uses a cross sectional approach with Structural Equation Modeling. The population in this study were all nurses in 44 public health centers in Tangerang Regency with a total of 290 nurses. The sample was selected by purposive sampling with a total of 82 respondents. Collecting data using a questionnaire. Work stress is influenced by workload by $18.07 \%$, support from colleagues by $17.59 \%$, work climate by $19.70 \%$, and work environment by $25.64 \%$. The model is able to explain the data variability of $99.74 \%$, while $0.26 \%$ is explained by other variables not examined in this study. Nurses are expected to create a conducive work environment such as maintaining good relationships with fellow nurses, supporting each other in achieving the work performance of their colleagues and maintaining the facilities provided by the puskesmas to support the work of nurses.
\end{abstract}

Keywords: Workload, work climate, work environment, coworkers, work stress.

Korespondensi*: Anna Riana, Program Studi Magister Kesehatan Masyarakat, Departemen Kesehatan Masyarakat Universitas Indonesia Maju, Gedung HZ Jl. Harapan No. 50, Lenteng Agung - Jakarta Selatan I 26 I0, Telp: (02 I) 78894045 


\section{Pendahuluan}

Secara keseluruhan di dunia, jumlah kasus COVID-19 sebanyak 81.104.164 jiwa dengan jumlah pasien meninggal sebanyak 1.771 .163 kasus $(0,45 \%){ }^{1}$ Penelitian sebelumnya telah melaporkan bahwa kondisi wabah infeksi, seperti sindrom pernafasan akut yang parah yang mirip dengan pandemi COVID-19, telah memberikan beban psikologis kepada para petugas kesehatan seperti kecemasan, depresi, serangan panik, atau gejala psikotik. $^{1}$ Satu hal yang dapat menyebabkan petugas kesehatan akan mengalami peningkatan kecemasan, salah satunya adalah kurangnya Alat Pelindung Diri (APD) di tempat kerjanya. Salah satu kelompok petugas terdampak adalah perawat. Petugas medis mendapatkan tekanan mental yang sangat besar, dikarenakan sering mendapatkan pekerjaan yang berlebih dengan tingkat risiko terpapar infeksius yang tinggi serta keletihan yang terus-menerus. ${ }^{2}$ Salah satu petugas kesehatan yang berperan menjadi garda terdepan penanganan COVID-19 adalah perawat.

Harus diakui bahwa banyak petugas kesehatan berada di garis depan wabah COVID-19, perlu memperhatikan profesional kesehatan yang bekerja di unit gawat darurat atau perawatan intensif dengan beban kerja yang lebih berat dan lebih stres daripada biasanya karena yang dirawat adalah pasien COVID-19. ${ }^{3}$ Menjaga kesehatan mental dan mengurangi risiko depresi, kecemasan atau kelelahan dalam situasi yang berkembang pesat ini bisa jadi sulit bagi petugas kesehatan. Selain itu, mereka sangat berisiko mengalami kerusakan moral ketika berhadapan dengan tantangan etis dari pandemi virus corona, seperti bekerja dalam kondisi kekurangan sumber daya, situasi triase, perawatan paliatif yang tidak memadai, dan ketidakmampuan untuk mendukung keluarga pasien yang sekarat. Petugas kesehatan berada pada risiko infeksi yang lebih tinggi, bekerja di bawah tekanan, stres kerja, jam kerja yang panjang, memiliki beban kerja yang tinggi dan terkadang tidak memiliki pelatihan yang tepat dan alat pelindung diri yang memadai serta lebih rentan terhadap diskriminasi. ${ }^{4}$

Keterlibatan perawat dalam menangani pasien COVID-19 menuntut adanya pengetahuan dan keterampilan pencegahan dan pengendalian infeksi yang tepat, serta update informasi dan perkembangan COVID-19. Keterlibatan manajemen keperawatan dalam penanganan COVID-19 guna mencegah terjadinya penularan dan perawatan pasien di ruang perawatan sangat dibutuhkan. Utama dari K3 yaitu faktor permasalahan untuk mencegah terpaparnya penyakit. Dukungan dari sekitar pekerja puskesmas, pemahaman petugas sangatlah penting untuk menjaga keselamatannya dalam pekerjaannya Perawat bisa mengalami tekanan dalam merawat penderita dengan virus korona COVID-19. Perawat bisa mengalami stres dan tertekan. Hal ini kerana perawat yang bekerja sebagai ujung tombak untuk pelayanan keperawatan dalam melayani semua kasus. ${ }^{5}$

Dalam melakukan tugas setiap harinya, perawat selalu berhubungan dengan kondisi pasien dengan berbagai penyakit serta resiko penularan, berhubungan juga dengan keluarga pasien dalam penyampaian komunikasi serta dokter dan peraturan atau prosedur operasional yang ada. Dari hal tersebut dapat menimbulkan beban yang berat dalam kerja yang menimbulkan masalah pada kondisi fisik, psikis serta emosionalnya. Stres yang dialami perawat harus diperhatikan, karena jika perawat telah mengalami stres yang tinggi maka dapat berdampak dengan kualitas pelayanan. ${ }^{6}$ Perawat yang mengalami stres memiliki perilaku gampang marah, gelisah, murung, cemas serta kurang semangat kerja. Oleh sebab itu, jika seorang perawat mengalami stres, maka menurunnya kinerja yang akhirnya dapat mendatangkan berbagai keluhan dari pasien. Stres dalam pekerjaan dapat menimbulkan masalah 
bagi seorang individu, lembaga, terlebih rekan kerja. Dampak pada individu dapat mengakibatkan gangguan kesehatan fisik serta mental, menurunkan kinerja, berkurangnya jenjang karir, serta hilangnya pekerjaan. Pada peristiwa berat, stres kerja bisa berdampak terhadap kendala tekanan mental. Pada lingkup lembaga, jika seseorang mengalami stress akan berdampak kepada kehadiran karyawan dan keluar masuk atau pergantian karyawan. Pada lingkup lingkungan rekan kerja, stress pekerjaan berdampak terhadap tekanan tinggi serta pelayanan jaminan rekan kerjanya, terutama bila persoalannya meningkat, maka akan menimbulkan ketiadaan pekerjaannya, pengangguran, ataupun berhenti karena alasan kesehatannya. ${ }^{7}$

$$
\text { Berdasarkan data Kabupaten }
$$

Tangerang, diperoleh jumlah perawat yang terkonfirmasi kasus COVID-19 sebanyak 234 orang, dengan rincian 58 berasal dari puskesmas dan 176 berasal dari rumah sakit. Dampak dari stres pekerjaan terusmenerus dialaminya bagi tenaga medis dapat membuat mantri menjadi terhambat dalam bekerja serta akan menimbulkan penyakit dari keadaan stres tersebut bahkan dapat berdampak pada kematian. Tujuan penelitian untuk mengetahui pengaruh langsung dan tidak langsung antara jumlah tangungjawab kinerja, dukungan rekan perkerja, lingkungan kerja serta ikllim kerja terhadap tingkat stress pada perawat puskesmas dalam penanganan COVID-19.

\section{Metode}

Jenis penelitian kuantitatif dengan desain cross-sectional. Penelitian ini dilakukan di Wilayah Kabupaten Tangerang pada bulan November 2020 sampai Januari 2021. Populasi penelitian adalah seluruh perawat di 44 puskesmas wilayah Kabupaten Tangerang dengan jumlah perawat sebanyak 290 orang. Sampel ialah beberapa kuantitas serta keunikan yang diperoleh melalui populasinya. ${ }^{8}$ Besar sampel ditentukan dengan teknik mengalikan jumlah indikator dengan 5-10, sehingga total 14 indikator, menghasilkan rentang sampel penelitian 70-140 responden. Sampel diperoleh secara purposive sampling dengan jumlah 82 responden.

Kriteria inklusi sampel diantaranya adalah perawat yang aktif bertugas memberikan pelayanan kepada pasien, dalam pengambilan menyetujui dan bersedia menjadi responden. Kriteria non inklusi yaitu tidak sebagai medis aktif bertugas memberikan pelayanan kepada pasien di Wilayah Kabupaten Tangerang. Kriteria eksklusi, diantanya perawat yang aktif bertugas memberikan pelayanan kepada pasien di Wilayah Kabupaten Tangerang namun kurang lengkapnya data pada saat mengisi angket serta keengganan sebagai informan. Data primer diperloeh dari kuesioner, sedangkan data sekunder diperoleh dari data yang ada di Puskesmas. Data disajikan dalam bentuk tekstual dan tabular untuk mendeskripsikan data yang diperoleh.

Penganalisaan dalam pendataaan berupa metode penggunaan aplikasi partial least square. Pemodelan refleksif memperkirakan komposisi ataupun faktor yang mendasari dipengaruhi parameter (jalur efek kausal melewati parameter kinerja). Penganalisa pemodelan setiap lajur disetiap parameter laten semuanya didalam pengunaan aplikasi ini terdapat 3 aturan: (1) Inner model pengkhususan berhubungan dengan variabel laten (structural model), (2) Outer model pengkhususan berhubungan dengan variabel laten melalui jalurnya atau parameter manifestnya (measurement model), (3) Weigth relation menghitung masalah parameter laten tetap diestimasi. Bila T-statistiknya >1,96, bisa diambil kesimpulan adanya dampak yang bermakna, bila penilaian $<1,96$, dapat disimpulkan tidak berpengaruh yang bermakna. $^{9}$ 
Hasil

Tabel 1 menunjukkan bahwa sebagian besar responden berada pada usia 30-45 tahun (80,5\%) dengan pendidikan sebagian besar responden adalah DIII keperawatan $(67,1 \%)$ dan lama bekerja responden adalah sama antara 6-15 tahun dan $>15$ tahun masing-masing sebanyak 41 responden $(50,0 \%)$.
Tabel 1. Distribusi Frekuensi Karakteristik Responden

\begin{tabular}{llcc}
\hline \multicolumn{1}{c}{ Variabel } & \multicolumn{1}{c}{ Kategori } & n & \% \\
\hline Usia & $30-45$ tahun & 66 & 80,5 \\
& $>45$ tahun & 16 & 19,5 \\
Pendidikan & SPK & 2 & 2,4 \\
& D3 Keperawatan & 55 & 67,1 \\
& S1 Keperawatan & 13 & 15,9 \\
& Profesi Ners & 12 & 14,6 \\
Lama Kerja & 6 - 15 tahun & 41 & 50,0 \\
& $>15$ tahun & 41 & 50,0 \\
\hline
\end{tabular}

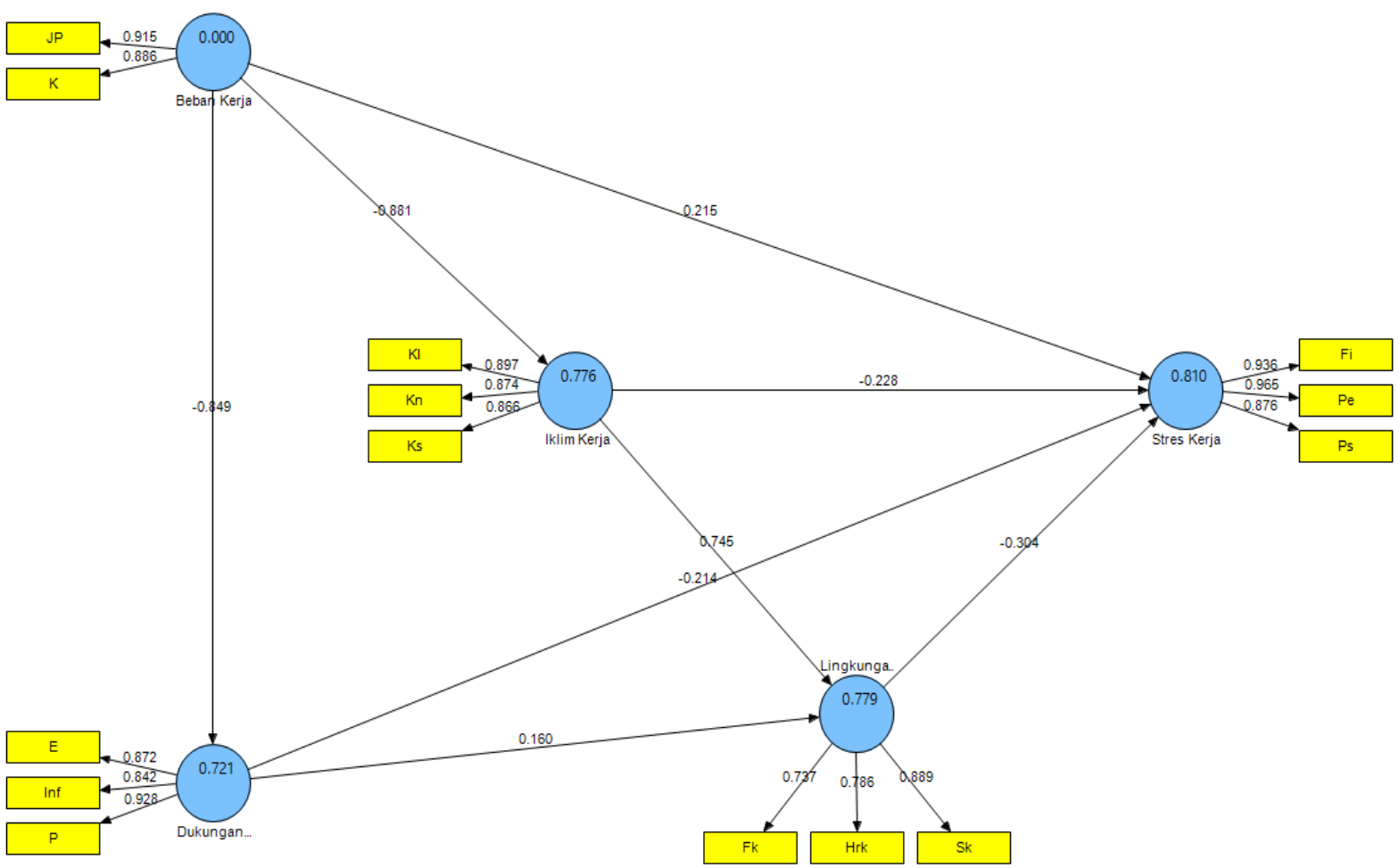

Gambar 1. Output PLS (Loading Factors)

Keterangan:

$\begin{array}{llllll}\mathrm{JP} & \text { : Jumlah Pekerjaan } & \mathrm{KI} & : \text { Kualitas } & \mathrm{Sk} & \text { : Suasana Kerja } \\ \mathrm{K} & : \text { Kecepatan } & \mathrm{Kn} & : \text { Kuantitas } & \mathrm{Fi} & \text { : Fisik } \\ \mathrm{E} & : \text { Emosional } & \mathrm{Ks} & : \text { Kebutuhan Supervisi } & \mathrm{Pe} & \text { : Perilaku } \\ \mathrm{Inf} & \text { : Informasi } & \mathrm{Fk} & \text { : Fasilitas Kerja } & \mathrm{Ps} & \text { : Psikologis } \\ \mathrm{P} & \text { : Penghargaan } & \mathrm{Hrk} & \text { : Hubungan Rekan Kerja } & & \end{array}$

Sesuai dengan loading factor mempunyai nilai $>0,5$ sehingga mempumyai standar pengujian untuk parameter pengukuran menyatakan diterima. Semua penilaian beban kepada metrik mengharapkan sangat besar daripada metrik lainnya, sehingga metrik tersebut dinyatakan valid. Semua variabel diyatakan sama karena penilaian AVE sangat tinggi 0,50 berarti memiliki validitas sangat bagus. Penilaian alpha cronbach $>0,70$. Selain itu, semua variabel dinyatakan reliabel jika nilai reliabilitas gabungannya $>0,70$. Kemudian dilakukan evaluasi model eksternal dan diperoleh hasil kajian model akhir untuk mengevaluasi model internal. Variabilitas beban kerja berkontribusi terhadap 
variabilitas dukungan rekan kerja sebesar $72,13 \%$ dan $27,87 \%$ dijelaskan oleh variabel lain yang tidak diteliti. Variabilitas beban kerja berkontribusi terhadap variabilitas iklim kerja sebesar $77,60 \%$ dan $22,40 \%$ dijelaskan oleh variabel lain yang tidak diteliti.

Selain itu, hasil gambar 1 menunjukkan variabilitas dukungan rekan kerja dan iklim kerja berkontribusi terhadap variabilitas lingkungan kerja sebesar 77,89\% dan 22,11\% dijelaskan oleh variabel lain yang tidak diteliti. Variabilitas beban kerja, dukungan rekan kerja, iklim kerja dan lingkungan kerja berperan serta kepada variasi stres kerja sebanyak $81,00 \%$ serta $19,00 \%$ dijelaskan oleh variabel lainnya yang bukan dari hasil penilitian ini. Sesuai dengan hasil bootstrapping yaitu:

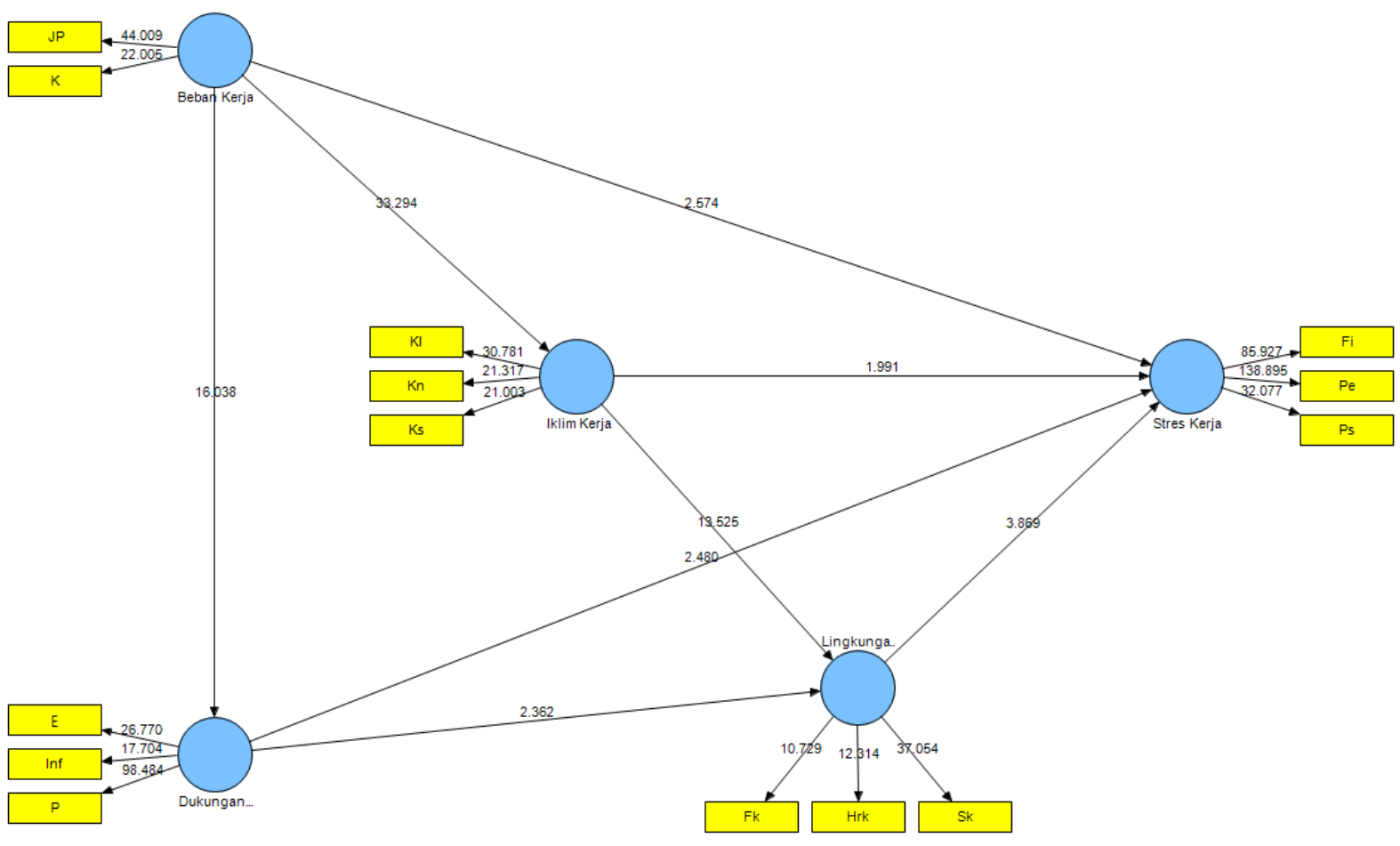

Gambar 2. Output PLS (T-Statistik)

Sesuai dengan nilai T-Statistic diperoleh hasil pengaruh negatif beban kerja terhadap dukungan rekan kerja. Hasil pengujian menunjukkan pengaruh negatif sebesar -0,849308, sedangkan sebesar 16,037725 yang signifikan pada alpha $5 \%$, dan nilai T-statistik lebih tinggi dari nilai kritis $(1,96)$. Beban kerja berpengaruh negatif terhadap suasana kerja. Hasil pengujian menunjukkan pengaruh negatif sebesar -0,880938, sedangkan nilai $T$ Statistic sebesar 33,294493 yang signifikan pada alpha $5 \%$, dan nilainya lebih tinggi dari nilai perseptif $(1,96)$. Stres pengaruh jelas, dan hasil pengujian menunjukkan pengaruh positif sebesar 0,214654, kemudian penilaian statistiknya 2,573526 yang relevan dengan alpha 5\%, dan peniliananya statistiknya lebih tinggi dari perseptif penilainya.

Dukungan rekan pekerja sangat terpengaruh tegas kepada lingkungan kerja, serta jumlah pengujian menerangkan terpengaruhnya dengan pasti sebesar 0,160205 , kemudian penilaian statistiknya 2,362189 yang bermakna pada alpha 5\%, dan penilaian statistiknya lebih tinggi dari perseptif penilaiannya. Dukungan rekan perkerja terpengaruh negatif kepada stres kerja, jumlah pengujian menghasilkan berpengaruhnya negatif sebesar $-0,213775$, kemudian penilaian statistiknya sebanyak 
2,479633 yang mempunyai makna pada alpha $5 \%$, dan penilaian statistiknya lebih tinggi dari perseptif penilaiannya.

Suasana kinerja terpengaruh perseptif kepada lingkungan kerja jumlah pengujian meghasilkan perseptif pengaruhnya sebesar 0,744847 , kemudian penilaian setatistiknya sebesar 13,525403 yang signifikan pada alpha $5 \%$, dan nilai T-Statistic lebih tinggi dari nilai kritis (1,96). Tekanan kerja berpengaruh negatif sebesar -0,228496, selanjutnya penilaian statistiknya adalah 1,991485 serta bermakna pada alpha $5 \%$, dan penilaian statistiknya lebih tinggi dari penilaian perseptif. Lingkungan kerja signifikan negatif terhadap stres kerja, jumlah pengujian menghasilkan ada berpengaruh negatif -0,303934, selanjutnya penilaian statistiknya sebesar 3,868878 serta mempunyai makna penilaian statistiknya mencapai penilaian perseptif.

Berikutnya melakukan penjumlahan untuk mendapati jumlah pengaruh langsung dan tidak langsung hubungan variabel eksogen terhadap endogen sesuai hitungan seperti ditampilkan pada tabel 2 .

Tabel 2. Persentase Pengaruh Langsung dan Tidak Langsung Beban Kerja, Dukungan Rekan Kerja, Iklim Kerja, dan Lingkungan Kerja terhadap Stres Kerja Perawat Puskesmas dalam Penanganan COVID-19

\begin{tabular}{lccccccc}
\hline \multicolumn{1}{c}{ Sumber } & $\begin{array}{c}\text { Latent Variable } \\
\text { Correlation }\end{array}$ & $\begin{array}{c}\text { Direct } \\
\text { Path }\end{array}$ & $\begin{array}{c}\text { Inderect } \\
\text { Path }\end{array}$ & Total & $\begin{array}{c}\text { Direct } \\
\text { \% }\end{array}$ & $\begin{array}{c}\text { Indirect } \\
\text { \% }\end{array}$ & $\begin{array}{c}\text { Total } \\
\text { \% }\end{array}$ \\
\hline Beban Kerja & 0,842 & 0,215 & 0,624 & 0,838 & 18,07 & 5,00 & 23,07 \\
Dukungan Rekan Kerja & $-0,823$ & $-0,214$ & $-0,049$ & $-0,262$ & 17,59 & 0,21 & 17,81 \\
Iklim Kerja & $-0,862$ & $-0,228$ & $-0,226$ & $-0,455$ & 19,70 & 1,12 & 20,82 \\
Lingkungan Kerja & $-0,844$ & $-0,304$ & & $-0,304$ & 25,64 & & 25,64 \\
\hline \multicolumn{2}{r}{} & Total & & & 81,00 & 6,34 & 87,34 \\
\hline
\end{tabular}

Berdasarkan tabel 2 menunjukkan adanya pengaruh langsung beban kerja sebesar $18,07 \%$ terhadap stress kerja perawat, dan pengaruh tidak langsung antara beban kerja terhadap stres kerja melalui dukungan rekan kerja dan iklim kerja sebesar $5,00 \%$. Dukungan rekan kerja berpengaruh langsung dan tidak langsung terhadap stres kerja. Pengujian koefisien parameter antara dukungan rekan kerja terhadap stres kerja didapatkan pengaruh langsung sebesar $17,59 \%$, dan pengaruh tidak langsung melalui lingkungan kerja sebesar $0,21 \%$.

Iklim kerja berpengaruh langsung dan tidak langsung terhadap stres kerja. Penjumlahan pengujian koefisien parameter iklim kerja terhadap stres kerja diketahui terdapat pengaruh langsung sebesar 19,70\%, dan pengaruh tidak langsung iklim kerja terhadap stres kerja melalui lingkungan kerja terdapat pengaruh sebesar $1,12 \%$. Lingkungan kerja berpengaruh langsung terhadap stres kerja. Penjumlahan pengujian koefisien parameter antara lingkungan kerja terhadap stres kerja didapatkan pengaruh langsung sebesar $25,64 \%$.

Penilaian terhadap tiap-tiap jalur pengaruh langsung variabel laten eksogen kesamaan antara variabel lainnya bila dilakukan bersamaan bisa dilihat dari nilai $R$ Square ataupun pernyataan oleh kemungkinan dengan faktor beban kerja, dukungan rekan kerja, iklim kerja, dan lingkungan kerja mampu menjelaskan variabel stres kerja sebesar $(18,07 \%+$ $17,59 \%+19,70 \%+25,64 \%)=81,00 \%$. Sedangkan pengaruh tidak langsung dari variabel beban kerja, dukungan rekan kerja, iklim kerja, dan lingkungan kerja terhadap variabel stres kerja sebesar $(5,00 \%+0,21 \%+1,12 \%)=6,34 \%$. Penjumlahan pengaruh langsung dan tidak langsung sebesar $87,34 \%$. Pemodelan ini dapat menerangkan variabilitas pendataaan sebesar 99,74\%, dan sebesar 0,26\% penjelasan diperoleh dari variabel lainnya yang tidak diteliti. 
Pembahasan

\section{Pengaruh Beban Kerja terhadap Stres Kerja}

Beban kerja berpengaruh positif terhadap stres kerja. Beban kerja berpengaruh secara langsung dan tidak langsung terhadap stres kerja. Hasil penelitian ini sejalan dengan penelitian yang dilakukan di Wuhan China, yang menemukan sejumlah 27 informan $(93,1 \%)$ bekerja melebihi waktu kerjanya. Stres kerja perawat sebagian besar adalah stres sedang sebanyak 24 responden $(82,8 \%)$. Hasil uji hipotesis disimpulkan ada pengaruh antara beban kerja dengan stres kerja perawat dengan nilai $T$-statistik sebesar 3,14. ${ }^{10}$

Salah satu faktor yang menyebabkan stres kerja yaitu beban kerja. Faktor beban kerja merupakan salah satu faktor yang dialami perawat pada saat ini pada penangan COVID-19. Beban kerja berlebih dapat berpengaruh terhadap kelelahan pada tenaga medis, yang diakibatkan karena kapasitas kerja yang berlebih dan tidak sesuai dengan pekerjaannya. Situasi ini bisa mengakibatkan stres pada pekerja, dikarenakan pasien yang berkunjung dapat dilayani dengan cepat agar dapat mendapatkan pelayanan dengan praktis. Kondisi ini dapat memicu munculnya stres kerja, karena semua pasien yang berkunjung secara tidak langsung menuntut mendapatkan pelayanan yang efektif dan baik supaya persoalan yang dikerjakan dapat diselesaikan dengan cepat. ${ }^{11}$ Penyebab dari kelebihan beban pekerjaan ialah keadaan konsumen yang tidak pasti, nilai kompetensi waktu merawat yang membutuhkan layanan cepat terhadap pasien diluar kemampuan pekerjaan yang normal pada umumnya, berkeinginan mendapatkan performa kinerja dan kehendak pekerjaannya banyak serta harus mendokumentasian asuhan keperawatan yang dilakukan. ${ }^{12}$

\section{Pengaruh Dukungan Rekan Kerja terhadap Stres Kerja}

Dukungan rekan kerja berpengaruh negatif terhadap stres kerja. Dukungan rekan kerja berpengaruh secara langsung dan tidak langsung terhadap stres kerja. Hasil penelitian ini sejalan dengan penelitian yang dilakukan oleh WHO dimana untuk dukungan rekan kerja nilai koefisien sebesar 7,291 dengan penilainan bermakna 0,000. Menunjukkan bahwa segmental dukungan rekan kerja dipengaruhi stres pekerjan. ${ }^{13}$

Konsep yang dipergunakan adalah model stres oleh, Usman di dalam acuan Holistik stress. Lebih mengarah dinamika stresnya secara spesifikasi. Acuan menggambarkan porses mengikutsertakan masalah stresnya, pertentangan individualnya yang bisa menyebabkan perihal stresnya serta distresnya untuk memenuhi coping strategi tertentu yang didapatkan dalam peristiwa fisik, jiwa, kesehatan mental, performa pekerjaaan, kesehatan pasangannya, status perkawinan, kapasitas merawat anaknya, karakter paner, serta partisipasi didalam komunitasnya. ${ }^{14}$ Stres kerja perawat juga perlu didukung oleh rekan kerja. Menjelaskan dukungan rekan kerja dapat berupa suatu bagian terpengaruhnya di dunia pekerjaan kecuali tuntutan serta stresornya. Semakin rendah dukungan rekan kerja berkemungkian tingkat stresnya tinggi di pekerjaanya. ${ }^{15} \mathrm{Di}$ lingkungan pekerjaan harus saling memercayai dalam pekrjaan, berpendapat, keterbukaan ataupun memberikan masukan dapat menghilngkan stres. Dorongan rekan kerja dapat menolong dan memenuhi kekurangannya dari sesorang pekerja kemudian bisa terhindar stres. ${ }^{16}$

\section{Pengaruh Iklim Kerja Terhadap Stres Kerja}

Iklim kerja berpengaruh negatif terhadap stres kerja. Iklim kerja berpengaruh secara langsung dan tidak langsung terhadap stres kerja. Hasil penelitian ini sejalan dengan penelitian yang dilakukan oleh Runtu yang menyatakan bahwa iklim organisasi 
berpengaruh terhadap stres kerja dengan nilai T-Statistiknya bermakna mendekati tingkat alphanya 5\% ialah sebanyak 2,664 $(>1,96)$ terhadap perbandingan lajur sebanyak 0,260. Dapat dibuktikan bahwa iklim institusi berpengaruh positif terhadap pekerjaan, semakin baik iklim kerja perawat maka stres kerja perawat juga akan cenderung rendah. ${ }^{17}$

Suasana pekerjaan ditentukan antara lain oleh temperatur udara, kelembaban, dan kelancaran pergerakan udara di ruang kerja. Iklim kerja merupakan kombinasi dari suhu udara, kelembaban, kecepatan pergerakan udara dan pancaran panas di lingkungan kerja. Lingkungan kerja yang terlalu dingin akan membuat orang merasa kedinginan dan lingkungan kerja yang terlalu panas akan membuat orang merasa tidak nyaman, yang akan mempengaruhi kelancaran pekerjaan. Iklim kerja organisasi berpengaruh besar pada proses menciptakan suana kerja yang kondusif, sehingga dapat menciptakan kerja sama yang harmonis pada setiap anggota di dalam suatu organisasi. Iklim organisasi ialah suatu kualitas lingkungan total dalam suatu organisasi yang ditunjukkan dengan bermacam-macam sifat antara lain terbuka, sibuk, hangat, santai, informal, dingin, impersonal, bermusuhan, kaku dan tertutup. $^{18}$

\section{Pengaruh Lingkungan Kerja terhadap Stres Kerja}

Lingkungan kerja berpengaruh negatif terhadap stres kerja. Lingkungan kerja berpengaruh secara langsung terhadap stres kerja. Hasil penelitian ini sejalan dengan penelitian yang dilakukan oleh Badri yang menyatakan bahwa lingkungan kerja perawat berpengaruh terhadap stres kerja. ${ }^{19}$

Lingkungan kerja sebagai salah satu penyebab dari keberhasilan dalam melaksanakan suatu pekerjaan juga dapat menyebabkan suatu kegagalan. Penyebab masalah yang dihadapi pekerja ialah pekerjaan yang berada didalam lingkungannya tidak sesuai serta ketidaknyamanan dapat menyebabkan kualitas pekerjaan serta prestasinya yang buruk. $^{20}$ Bila petugas kesehatan berada dalam lingkungan yang tidak mendukung seperti komposisi kerja serta ketidakcocokannya pengelolaan terhadap jati diri pekerjaan, dapat menyebabkan kendala pada keakraban sesama pekerja maupun terhadap pimpinannya. Interaksi antara individu di dalam lingkungan pekerjaan dapat berdampak negatif seperti memacu kejadian perselisian serta permasalahan di dalam pekerjaan. Namun juga dapat berdampak positif seperti membentuk lingkungan kerja yang sangat bersemangat karena adanya adaptasi terhadap dunia luar dan dalam karena pengaruh globalisasi, berita dari teknologi, obsesi kualitas yang bisa berdampak terhadap perselisihan antar rekan kerja. ${ }^{21}$

\section{Kesimpulan}

Dari hasil penelitian ini dapat disimpulkan adanya pengaruh langsung serta tidak langsung beban kerja, dukungan rekan kerja, iklim kerja dan lingkungan kerja terhadap stres kerja perawat puskesmas dalam penanganan COVID-19 di Wilayah Kabupaten Tangerang tahun 2021. Variabel yang berpengaruh paling besar terhadap stres kerja perawat puskesmas di wilayah Kabupaten Tangerang adalah variabel lingkungan kerja. Interaksi antara individu dalam lingkungan kerja dapat menimbulkan dampak negatif yang memicu terjadinya masalah dalam pekerjaan, memengaruhi globalisasi, ledakan informasi melalui teknologi, obsesi kualitas, yang dapat menimbulkan terjadinya stres di tempat kerja.

\section{Saran}

Saran peneliti untuk perawat puskesmas dalam penanganan COVID-19 di Wilayah Kabupaten Tangerang adalah diharapkan menciptakan lingkungan kerja yang kondusif seperti menjaga hubungan yang baik dengan sesama rekan perawat, saling mendukung dalam pencapaian 
prestasi rekat sejawatnya dan menjaga fasilitas yang diberikan oleh puskesmas untuk menunjang kerja perawat. Diharapkan untuk penelitian selanjutnya, menggunakan metode mix-method untuk dapat informasi lebih mendalam terkait variabel yang diteliti.

\section{Daftar Pustaka}

1. Kemkes RI. Peta Sebaran COVID-19. Jakarta: Kemkes RI; 2021.

2. Rosyanti L., \& Hadi I. Dampak Psikologis dalam Memberikan Perawatan dan Layanan Kesehatan Pasien COVID-19 pada Tenaga Profesional Kesehatan. Health Information: Jurnal Penelitian, 12(1), Desember 2020, 107$130 . \quad$ https://myjurnal.poltekkeskdi.ac.id/index.php/HIJP/article/view/191/158

3. Hanggoro A. Y., Suwarni L., Selviana S., \& Mawardi M. Dampak Psikologis Pandemi COVID-19 pada Tenaga Kesehatan: A Studi Cross-Sectional di Kota Pontianak. Jurnal Kesehatan Masyarakat Indonesia. 15(2), Agustus 2020, 13-18. https://jurnal.unimus.ac.id/index.php/jkmi/arti cle/view/6585/5099

4. Liu C. Y., Yang Y. Z., Zhang X. M., Xu X., Dou Q. L., Zhang W. W., \& Cheng A. S. K. The Prevalence and Influencing Factors in Anxiety in Medical Workers Fighting COVID-19 in China: A Cross-Sectional Survey. Epidemiology and Infection, Juni 2020, 148. https://www.ncbi.nlm.nih.gov/pmc/articles/P MC7251286/

5. Hacimusalar Y., Kahve A. C., Yasar A. B., \& Aydin M. S. Anxiety and Hopelessness Levels in COVID-19 Pandemic: A Comparative Study of Healthcare Professionals and Other Community Sample in Turkey. Journal of Psychiatric Research, 129 (July 2020), 181188.

https://www.ncbi.nlm.nih.gov/pmc/articles/P MC7372275/

6. Teng Z., Wei Z., Qiu Y., Tan Y., Chen J., Tang H., Wu H., Wu R., \& Huang J. Psychological Status and Fatigue of Frontline Staff Two Months After The COVID-19 Pandemic Outbreak in China: A CrossSectional Study. Journal of Affective Disorders, 275(July 2020), 247-252. https://www.ncbi.nlm.nih.gov/pmc/articles/P MC7330556/

7. Temsah M. H., Al-Sohime F., Alamro N., AlEyadhy A., Al-Hasan K., Jamal A., AlMaglouth I., Aljamaan F., Al Amri M., Barry M., Al-Subaie S., \& Somily A. M. The Psychological Impact of COVID-19 Pandemic on Health Care Workers in a Mers-CoV
Endemic Country. Journal of Infection and Public Health, 13(6), Maret 2020, 877-882. https://www.ncbi.nlm.nih.gov/pmc/articles/P MC7256548/

8. Nursalam. Metode Penelitian Ilmu Keperawatan: Pendekatan Praktis. Jakarta: Salemba Medika; 2017.

9. Ghozali, I. Structural Equation Modeling Metode Alternatif Dengan Partial Least Square (PLS). Semarang: Badan Penerbit Universitas Diponegoro; 2016.

10. Hu D., Kong Y., Li W., Han Q., Zhang X., Zhu L. X., Wan S. W., Liu Z., Shen Q., Yang J., He H. G., \& Zhu J. Frontline Nurses Burnout, Anxiety, Depression, and Fear Statuses and Their Associated Factors During The COVID-19 Outbreak in Wuhan, China: A Large-Scale Cross-Sectional Study. Eclinical Medicine, Februari 2020, 24. https://www.ncbi.nlm.nih.gov/pmc/articles/P MC7320259/

11. Mudayana A. A, Pengaruh Beban Kerja Terhadap Stres Kerja Karyawan di Rumah Sakit Nur Hidayah Bantul. Jurnal KESMAS Universitas Ahmad Dahlan Vol 6. No. 1, Januari 2017, Hal. 35-40. http://journal.uad.ac.id/index.php/KesMas/arti cle/view/1065/pdf

12. Korkmaz S., Kazgan A., Çekiç S., Tartar A. S., Balc1 H. N., \& Atmaca M. The Anxiety Levels, Quality of Sleep and Life and Problem-Solving Skills in Healthcare Workers Employed in COVID-19 Services. Journal of Clinical Neuroscience, 80, September 2020, 131-136.

https://www.ncbi.nlm.nih.gov/pmc/articles/P MC7425768/

13. WHO. Stress Associated With COVID-19: A Guide to Preventing and Addressing. Geneva: WHO; 2020.

14. Usman S. Penyakit Penyerta dan Tingkat Stres maupun Kecemasan pada Pasien Diabetes Melitus di Puskesmas Pengasih 1 Kulon Progo. Dinamika Kesehatan: Jurnal Kebidanan Dan Keperawatan, 11(1), Maret 2019, 37-48. https://journal.ppnijateng.org/index.php/jpi/art icle/view/199/148

15. Fadli F., Safruddin S., Ahmad A. S., Sumbara S., \& Baharuddin R. Faktor yang Mempengaruhi Stres pada Tenaga Kesehatan dalam Upaya Pencegahan COVID-19. Jurnal Pendidikan Keperawatan Indonesia, 6(1), Juni 2020,

57-65. https://vm36.upi.edu/index.php/JPKI/article/vi ewFile/24546/pdf

16. Cheng Cai, H., Tu B., Ma J., Chen L., Fu L., Jiang Y., \& Zhuang Q. Psychological Impact and Coping Strategies of Frontline Medical Staff in Hunan Between January and March 2020 During the Outbreak of Coronavirus 
Disease 2019 (COVID-19) in Hubei, China. Medical Science Monitor: International Medical Journal of Experimental and Clinical Research, 26, Juni 2020, e924171-1. https:/www.ncbi.nlm.nih.gov/pmc/articles/P MC7177038/

17. Runtu. Iklim Kerja terhadap Stres Kerja Perawat IGD RSUD Pasar Rebo. Jurnal Ilmu Kesehatan Bhakti Husada, 10(2), November 2016, 142-149. http://journal.ui.ac.id/index.php/arsi/article/vie w/5218/3503

18. Roberts N. J., McAloney-Kocaman K., Lippiett K., Ray E., Welch L., \& Kelly C. Levels of Resilience, Anxiety and Depression in Nurses Working in Respiratory Clinical Areas During The Covid Pandemic. Respiratory Medicine, 176, Juli 2020, 106219. https://www.ncbi.nlm.nih.gov/pmc/articles/P

\section{MC7648185/}

19. Badri. Pengaruh Lingkungan Kerja Terhadap Stres pada Kondisi Wabah COVID-19. Jurnal Penelitian Psikologi, 7(2), Februari 2020, 5976. https://ibn.ejournal.id/index.php/ESENSI/article/view/205 $/ 181$

20. Abudy R. Stres Kerja Perawat Terhadap Penanganan Orang Positif COVID-19. Jambura Jurnal. 2(2), Desember 2020, 31-42. http://jurnal.globalhealthsciencegroup.com/ind ex.php/JPPP/article/view/429/297

21. Iswanto D. Pengaruh Lingkungan Terhadap Stres pada Mahasiswa Aktivis Organisasi UIN SUSKA RIAU. [Tesis]. Pekanbaru: Fakultas Psikologi Universitas Islam Negeri Sultan Syarif Kasim Riau; 2017. http://repository.uin-suska.ac.id/30011/ 